\title{
Exploring China's Arctic Strategy: Opportunities and Challenges
}

Serafettin Yilmaz

\begin{abstract}
China's understanding of the Arctic covers two major dimensions. One is that the Arctic is an international sphere, and the other is that China should be regarded as a "near Arctic state." Based on such understanding, China's Arctic policy has been evolving along a variety of considerations, such as securing investment and resources, pursuing sealanes of communication and trade, and facilitating strategic reach and power projection. China seeks to increase its strengths by carrying forward its own national initiatives including scientific research, trade and investment, and power projection, as well as through participation in bilateral and multilateral cooperation and collaboration schemes. As China views the Arctic from the perspectives of both low and high politics, it is anticipated that China will be further engaged in Arctic affairs with a conceptually and materially sound Arctic strategy, under
\end{abstract}

Serafettin Yilmaz is a postdoctoral researcher at the School of Political Science and Public Administration, Shandong University. His mailing address is No. 5, Hongjialou Building, Licheng District, Jinan 250100, China. He can also be reached at syilmaz1864@yandex. com.

(C) 2017 World Century Publishing Corporation and Shanghai Institutes for International Studies China Quarterly of International Strategic Studies, Vol. 3, No. 1, 57-78

DOI: 10.1142/S237774001750004X 
which a closer partnership with Arctic states, especially Russia, is a necessary step.

Keywords: China's Arctic strategy; "near Arctic state"; the Arctic Circle; peaceful utilization; cooperation mechanism.

A number of regional and non-regional actors are more forcefully involved in the Arctic development, due to the opening-up of once inaccessible corridors for shipping and the easier access to mineral, hydrocarbon and fishery deposits as a result of the melting ice. Over the years, various states and groups such as the United States, Russia, Norway, Canada, Denmark, Finland, Sweden, the North Atlantic Treaty Organization (NATO) and the European Union (EU) have been elaborating on their Arctic policies. ${ }^{1}$

In January 2009, the White House issued two policy papers on the Arctic issue, laying out the fundamentals of the U.S. Arctic policy, which were first related to such national security interests as "missile defense and early warning; deployment of sea and air systems for strategic sealift, strategic deterrence, maritime presence and maritime security operations; and ensuring freedom of navigation and overflight"; second, to global governance including the contention that "the geopolitical circumstances of the Arctic region differ sufficiently from those of the Antarctic region such that an 'Arctic Treaty' of broad scope - along the lines of the Antarctic Treaty — is not appropriate or necessary"; and third, to scientific development, maritime transportation and energy and resources. ${ }^{2}$ In October 2009, the U.S. Chief of Naval Operations issued U.S. Navy Arctic Road Map, stating that the U.S. Navy remains committed to naval activities in the Arctic and is against any provision that limits or prevents its capabilities to effectively train and operate in the region. Released in 2013, the National Strategy for the Arctic Region also suggested that the U.S. government should

${ }^{1}$ The five Arctic littoral states are Canada, Denmark (of which Greenland is an autonomous territory), Norway, Russia and the United States (by virtue of Alaska). Three other countries (Finland, Iceland and Sweden) have territory in the Arctic Circle.

${ }^{2}$ The White House, "National Security Presidential Directive 66 and Homeland Security Presidential Directive 25," January 2009, https://www.nsf.gov/geo/plr/opp_advisory/ briefings/may2009/nspd66_hspd25.pdf. 
have an aggressive agenda to explore resources in the Arctic and set goals to reinforce defense, law enforcement, as well as search and rescue capacities. ${ }^{3}$ In March 2016, the U.S. government released two reports on the Arctic region, among which the document entitled 2016 Implementation Framework for the National Strategy for the Arctic Region identified advancing U.S. security interests in the Arctic as the primary "line of effort," referring to the maritime, aviation and infrastructure domains. ${ }^{4}$

In a similar vein, the Security Council of the Russian Federation released Fundamentals of the Russian Federation's Policy in the Arctic for the Period up to 2020 and Beyond in 2009. The policy paper defines the Arctic Zone of Russia and details its utilization on three levels: as a strategic resource base, as a zone of peace and cooperation, and as a unified national transport link, referring specifically to the development of the Northern Shipping Route (NSR) as a viable sea lane of communication. On the issue of military security, the document states that creation of military groups in the Arctic zone and optimization of integrated control systems over the Arctic should be further pursued. ${ }^{5}$

Although three of its member states are in the Arctic Council (Denmark, Sweden, Finland), the EU has yet to obtain a permanent observer status in the organization. However, the EU has been increasingly vocal about Arctic affairs. In October 2008, the European Parliament adopted a resolution on Arctic governance, calling for opening international negotiations on an Arctic Treaty in a similar fashion as the Antarctic Treaty, but received criticism from some of the Arctic Council states; the EU has since abandoned the idea. $^{6}$ A month later, the EU Commission issued a

${ }^{3}$ The White House, "National Strategy for the Arctic Region," May 10, 2013, https:// www.whitehouse.gov/sites/default/files/docs/nat_arctic_strategy.pdf.

${ }^{4}$ The White House, "Advancing Implementation of the National Strategy for the Arctic Region," March 9, 2016, https://www.whitehouse.gov/blog/2016/03/09/advancingimplementation-national-strategy-arctic-region.

5“Osnovy gosudarstvennoy politiki Rossiyskoy Federatsii v Arktike na period do 2020 goda i dal'neyshuyu perspektivu [Fundamentals of the Russian Federation's State Policy in the Arctic until 2020 and Beyond]," Rossiyskaya Gazeta, March 27, 2009, https://rg.ru/2009/03/ 30/arktika-osnovy-dok.html.

${ }^{6}$ The European Parliament, "European Parliament Resolution of 9 October 2008 on Arctic Governance," October 9, 2008, http://www.europarl.europa.eu/sides/getDoc.do? type $=$ TA\&reference $=$ P6-TA-2008-0474 \&language $=E N$. 
document detailing the EU's interests and objectives with respect to the Arctic. In addition to mentioning the issues of resource extraction and transportation, the policy paper also refers to climate change as a nontraditional security challenge and highlights the risk of a clash of interests among states over Arctic resources.

\section{China's Understanding of and Engagement in the Arctic}

Compared with the United States, Russia and the EU in developing the Arctic policy, China still lacks a broad perspective on the issue at present, since the Chinese government has neither announced a comprehensive Arctic policy nor released a detailed multidimensional Arctic strategy. Fortunately, governmental and non-governmental agencies, policy analysts and scholars have offered invaluable insights and ideas, generating an evolving national discourse on the Arctic. Meanwhile, a significant amount of diplomatic and economic resources has been invested to construct a strategic road map based on solid understanding of the Arctic's geopolitics and geo-economics.

China's understanding of the Arctic comprises two major dimensions. One is that the Arctic is essentially an international sphere. While Beijing recognizes the sovereign rights of the five Arctic littoral states under international law and conventions, it holds the view that a larger (and increasingly more ac-

China is lagging behind other major powers in laying out a comprehensive Arctic strategy. cessible) portion of the Arctic is an international water and belongs to humanity as a whole. The other is that China is a "near Arctic state," although it does not border the Arctic; and thus, in line with the growth of its economic and strategic reach, China should view itself as having strong interests in Arctic affairs.

Based on the fundamental understanding of the Arctic as an international sphere, the Chinese government, along with the country's strategists and scholars, has stressed the need to ensure the protection of rights and interests of non-Arctic states under an international framework. ${ }^{7}$ Arctic

${ }^{7}$ Song Lilei, “Beiji Zhili yu Zhongguo de Beiji Zhengce [Arctic Governance and China's Arctic Policy]," Guowai Lilun Dongtai [Foreign Theoretical Trends], August 2015, pp. 112-120. 
countries are urged to maintain a balance between the interests of states with shorelines in the Arctic Ocean and the shared interests of the entire international community. China's former ambassador to Norway, Tang Guoqiang once remarked that

\begin{abstract}
China's Arctic policy should be a component part of China's foreign policy. Its basic elements should be: in the spirit of peaceful development of the Arctic for the benefit of mankind and on the basis of mutual respects and enhanced understanding and trusts, China will develop a normal relationship of win-win cooperation with the Arctic countries and the international community...8
\end{abstract}

Another point that has been emphasized with respect to Arctic governance is the value of China's participation within the existing international framework and the implications of China being sidelined, which would force it to seek and protect its strategic interests unilaterally. ${ }^{9}$

Moreover, even though it is not an Arctic state in the geographical sense, China views itself as a "near Arctic" country and has been increasingly vocal about its interests in the region's passageways, resources and international waters. It perceives that Arctic-related issues are of an international nature beyond geographic proximity and national jurisdiction. The Chinese government has emphasized the importance of the Arctic region for the country's "environment, economy, society, and consequently, the trajectory of its sustainable development", whereas China's strategists have stressed the possibility for the Arctic region to become both a theater of militarized competition over the control of the sea routes and resources, and a ground for military power projection over three continents. ${ }^{10}$

\footnotetext{
${ }^{8}$ Tang Guoqiang, “Arctic Issues and China's Stance," CIIS, March 4, 2013, http://www. ciis.org.cn/english/2013-03/04/content_5772842.htm.

${ }^{9}$ Ding Huang and Zhang Chong, "Zhongguo Canyu Beiji Zhili de Jiazhi Fenxi — Jiyu Xin Ziyou Zhidi Zhuyi de Shijiao Chuban Yuan [An Analysis of the Value of China's Participation in Arctic Governance - From the Perspective of Neoliberal Institutionalism]," Wuhan Daxue Xuebao [Journal of Wuhan University], Vol. 69, No. 3, 2016, pp. 23-29.

${ }^{10}$ Caitlin Campbell, "China and the Arctic: Objectives and Obstacles," U.S.-China Economic and Security Review Commission Staff Research Report, April 13, 2012, http://origin. www.uscc.gov/sites/default/files/Research/China-and-the-Arctic_Apr2012.pdf.
} 
In order that it becomes an essential part of the Arctic economic and strategic regime, China has been increasingly engaged in Arctic affairs since the early 1980s. Important steps have been taken in terms of institutional participation, scientific research, development cooperation and, to a lesser degree, sea-lanes utilization. Officials have also reiterated the international nature of the region, and expressed their expectation that Arctic governance would not exclude non-Arctic states from participation in policy formulation and management. For a greater say in Arctic affairs, China has allocated more diplomatic and economic resources in recent years for Arctic research and development, and has taken further steps such as joining the Arctic Council as a permanent observer, establishing partnerships with Russia and several Nordic countries like Iceland and Sweden, initiating the buildup of the second polar icebreaker and the second research facility in cooperation with Iceland, and conducting more frequent Arctic expeditions. ${ }^{11}$

Although China has no territory in the Arctic, its economic and strategic presence in the region has been growing. It is thus necessary for the Chinese government to mobilize national resources, take an active part in Arctic-related institutions, and establish multilateral and bilateral cooperation frameworks. The most significant step so far is China's admission to the Arctic Council in May 2013, which enables China to voice its positions and initiate talks with relevant powers in Arctic governance. In addition to joining the multilateral Arctic Council, Beijing has been improving bilateral communication with individual states along the Arctic Circle. China attempts to position itself as a reliable partner in various Arctic schemes with respect to such areas as mining, fishing and sea-lane development. For example, both Denmark's and Greenland's authorities welcomed China's potential role in the development of Greenland's mining and fishing industries. ${ }^{12}$ In fact, bilateralism has been an essential part of China's Arctic

\footnotetext{
${ }^{11}$ Nonetheless, polar research still receives only a fraction of the central government's funding for research, and Antarctic research gets a bigger share of the allocated funds. By 2016, China had done 32 Antarctic expeditions, as compared with only 7 Arctic expeditions. The $33^{\text {rd }}$ Antarctic expedition is currently going on. See Dorothee Thiesing and Jill Lawless, "China's Arctic Ambitions Take Shape in Remote Iceland Valley," The Associated Press, November 16, 2016, http://www.ctvnews.ca/world/china-s-arctic-ambitions-take-shape-inremote-iceland-valley-1.3163276.

${ }^{12}$ Kevin McGwin, “China's Arctic Allies,” The Arctic Journal, February 19, 2014, http:// arcticjournal.com/oil-minerals/433/chinas-arctic-allies.
} 
engagement, which also underlies the non-contentious characteristics of its overall strategy ${ }^{13}$ of scientific research and resource development. ${ }^{14}$ The Chinese government also views itself as a crucial stakeholder in Arctic affairs, not only in scientific research, but also in sea-lane security, natural resource exploration and a potential militarization. ${ }^{15}$

\section{China's Arctic Policy Considerations}

Based on the general understanding and practical considerations, China's Arctic policy has been in progress. ${ }^{16}$ First and foremost, China would like to secure the availability of mineral, hydrocarbon and fishing resources in the Arctic and has set up several cooperation schemes with Arctic territorial states such as Iceland and Greenland.

According to a U.S. geological survey, the Arctic region is abundant in undiscovered resources, including 30 percent of the world's gas reserves, 13 percent of crude oil reserves, 9 percent of coal reserves as well as other economically critical minerals such as uranium. ${ }^{17}$ More specifically, the survey estimates that the Arctic contains a potential 90 billion barrels of undiscovered oil ${ }^{18}$ and 1,670 trillion cubic feet (47 trillion cubic meters) of undiscovered natural gas, which represents 13 percent of undiscovered oil and 30 percent undiscovered natural gas in the world. ${ }^{19}$ It is also noted that

13“China Defends Arctic Research Missions,” China Daily, February 1, 2012, http://usa. chinadaily.com.cn/china/2012-02/01/content_14514030_2.htm.

${ }^{14}$ Zhou Siyu, "Warming to the Idea of Arctic exploration," Xinhua, May 13, 2013, http:// www.chinadaily.com.cn/business/2013-05/13/content_16493720.htm.

15 "Chinese FM: China an Important Stakeholder in Arctic," Ministry of Foreign Affairs, PRC, (Third Arctic Council Assembly meeting, Iceland), October 19, 2015, http://www. fmprc.gov.cn/mfa_eng/sp/t1307098.shtml.

${ }^{16}$ The Chinese Arctic and Antarctic Administration (CAA) was set up in 1981 while the Polar Research Institute of China (PRIC) was founded in 1989. Both institutions are affiliated to the State Oceanic Administration.

${ }^{17}$ D. L. Gautier et al., "Assessment of Undiscovered Oil and Gas in the Arctic," United States Geological Survey, 2009, https://pubs.er.usgs.gov/publication/70035000.

${ }^{18}$ Considering that China's daily oil consumption is around 10 million barrels, the estimated amount equals over 24 years of national consumption.

19“Arctic Council, Arctic Marine Shipping Assessment 2009 Report," Arctic Council, April 2009, p. 9, https://oaarchive.arctic-council.org/handle/11374/54. 
the Arctic may hold significant reserves of other metals and rare earth minerals as well. Thus, although most of the Arctic deposits of hydrocarbons and minerals are currently inaccessible, they offer a huge potential for future development.

The United States, Russia, Canada and Norway, countries that possess Arctic land and sea territories, have long been exploring Arctic hydrocarbon resources. China obviously intends to take part in the exploration and utilization of the actual and potential resources in cooperation with regional governments and institutions. It has been reported that several

Tapping natural resources is China's primary concern in shaping its Arctic policy. Chinese companies are in talks to develop minerals such as iron ore and copper in the Arctic. However, although there have been exploration activities by various Chinese entities, the production phase has not yet begun. Given that an overwhelming 84 percent of undiscovered oil and gas resources are anticipated to be found either offshore or "close to the areas that are not subject to territorial disputes," the prospects for bilateral cooperation are high. ${ }^{20}$

The most accessible and thus less costly areas of hydrocarbon exploration are the Russian and Norwegian Barents Sea shelf. Another area of potential exploration is West Greenland in which several wells have been drilled since 2010. Currently, hydrocarbon exploration in the Arctic is costly from both the technological and financial perspectives. According to available data, for example, in 2005, "the cost of drilling an onshore well in Alaska was estimated to be about $640 \%$ higher than the average cost of drilling wells in the U.S. as a whole." ${ }^{21}$ However, provided that there is strong demand, Arctic drilling is likely to continue at an accelerating pace.

The Arctic is also estimated to have rich mineral deposits and the mining of these resources predates hydrocarbon explorations. Mineral mining appears to be more developed and diversified than that of

${ }^{20}$ Arnfinn Jørgensen-Dahl, “Arctic Oil and Gas," CHNL, 2010, http://www.arctis-search. $\mathrm{com} /$ Arctic + Oil + and + Gas\&structure $=$ Arctic + Energy + and + Mineral + Resources.

${ }^{21}$ Ibid. 
hydrocarbons. Coal deposits in the region were already being exploited in the early 20th century. Russia, Alaska, Greenland, Canada and other Scandinavian states are actively engaged in mining activities, exploiting a wide variety of minerals such as nickel, palladium, platinum, zinc, lead, gold, copper, and other rare earth materials. Under the present geopolitical conditions, it is more likely for China to work with Russia, the Nordic countries and Greenland rather than the United States or Canada.

The Arctic is also home to extensive fishing grounds which might potentially be "the world's largest storehouse of biological protein." ${ }^{22}$ The diminishing of ice opens the Central Arctic Ocean (which is considered as one of the world's richest fisheries) to international commercial fishing. An international framework is thus needed to ensure the management of the area's biodiversity and regulate fishing. In this regard, although the five Arctic coastal countries reached a consensus in April 2014 that commercial fishing should not start in the international waters until adequate scientific studies are conducted in the region, some high sea areas were reported to be already suffering from over-fishing in the absence of a binding international regulation. ${ }^{23}$ China also showed interest in fishing in the Arctic, and in January 2015, a conference on Arctic fishing was held in Shanghai, the first ever in China.

Second, China hopes to build capability and ensure access to the sealanes of communication along the Arctic region; it conducted its first Arctic passage in 2012 and has launched several expeditions to the region ever since.

There are three major corridors that pass through the Arctic Ocean. The Northern Sea Route (NSR, also called as the Northeast Sea Route or Sevmorput in Russian) along the vast north Siberian region and the Northwest Sea Route (NWR) along the Canadian archipelago lying in the north-south direction. The third route, the Transpolar Passage or Arctic

${ }^{22}$ Tang Guoqiang, "Beiji Wenti yu Zhongguo de Zhengce [The Arctic Problem and China's Policy]," CIIS, February 6, 2013, http://www.ciis.org.cn/gyzz/2013-02/06/ content_5727672.htm.

${ }^{23}$ Bob Weber, "Canada Agrees to Craft Deal Blocking High Arctic Fishing," The Globe and Mail, February 27, 2014, http://www.theglobeandmail.com/news/politics/canada-agreesto-craft-deal-blocking-high-arctic-fishing/article 17138891/. 
Bridge, stretches across the North Pole, connecting Pacific and Atlantic ports. None of these passages offers a single route, but rather several broad corridors for navigation on which transportation takes place based on the ice and navigational conditions. ${ }^{24}$ The NSR was opened to international transport in 1991 and is more navigable than the NWR since it is more accessible - at times, the latter remains impassable even in late summer.

The Arctic is now being forced open by climate change, which is the reason why there is growing interest in the region as a potential alternative passage for time- and cost-efficient trade. Even though "no research and none of the GCM [General Circulation Model] simulations have indicated that the winter sea ice cover of the Arctic Ocean will disappear during this century," it is still observed that "coastal Arctic regions [are becoming] increasingly ice-free or nearly ice-free for longer summer and autumn seasons." Thus, even if "no commercial cargo ship has yet to cross the central Arctic Ocean, there have been trans-Arctic voyages during the summer season along the Russian Federation's Northern Sea Route and the Northwest Passage in the Canadian Arctic." ${ }^{25}$

The prospect for shipping along NSR and NWR is still bleak. ${ }^{26}$ For both passageways, sea traffic peaked in 2013 and has been in decline ever since. China's Xue Long icebreaker became the first Chinese vessel to pass through the Northern Sea Route in 2012. ${ }^{27}$ One year later, the first Chinese commercial ship sailed from Dalian to Rotterdam through the NSR. However, China's commercial activity along the NSR has never been very active. Even at the peak of shipping activities along the NSR in 2013, only one out of 71 vessels that passed along the NSR was China-flagged. The low utilization might also have to do with the inadequate infrastructure along the NSR that fails to respond to the risks inherent in Arctic transport. The available data, therefore, makes the prediction, that by 2020, 2 to 15 percent

${ }^{24}$ Willy Østreng, "The Transportation Passages of the Arctic Ocean," CHNL, 2010, http://www.arctis-search.com/The+Transportation+Passages+of +the+Arctic+Ocean\& structure $=$ Arctic + Sea + Routes .

${ }^{25}$ The Arctic Council, "Arctic Council, Arctic Marine Shipping Assessment 2009 Report," April 2009, pp. 28 and 35, https://oaarchive.arctic-council.org/handle/11374/54.

${ }^{26}$ Ibid., p. 102.

${ }^{27}$ So far, Xue Long has completed seven Arctic expeditions in 1997, 2003, 2008, 2010, 2012, 2014, and 2016. 
of China's international trade would use the Arctic route, merely a distant likelihood. ${ }^{28}$

As observed in Table 1, although the Arctic sea routes are not used as extensively as other sea-lanes, China is still optimistic about the future prospects. Hence, China's Maritime Safety Administration issued two guidelines for ships traversing through the Northeast and Northwest Routes in 2014 and 2015 respectively, to assist and encourage shipping in the Arctic. Chinese officials expect that in the future "'there will be ships with Chinese flags sailing through this route in the future' as it would save time and money for Chinese ship owners." ${ }^{29}$ It is apparent that China views the Arctic as a trade route with great potential despite the present underutilization. In fact, in the long term, China sees the Arctic route as the northern link in its broader "Belt and Road" initiative. ${ }^{30}$ China's optimism is shared by actors that are more involved in Arctic management. For example, in the report Arctic Council Marine Shipping Assessment, it has been underlined that regular trans-polar summer transport (four months) will begin in 2040 and "future Arctic marine activity will include many non-Arctic stakeholders, multiple users in Arctic waterways and potential overlap of new operations with indigenous uses." ${ }^{31}$

The potential of the Arctic routes lies in the advantages they offer. Estimations have showed that trans-polar shipping would shorten a trip from Shanghai to Rotterdam by more than 6,000 miles compared to the traditional route along the Malacca Strait and the Suez Canal, which would save considerable costs. Hence, the question now is not whether the Arctic transportation would be possible, but who would benefit the most from the disappearing of the sea ice in some segments of the Arctic and whether

${ }^{28}$ Trude Pattersen, “China Starts Commercial Use of Northern Sea Route," Barent Observer, March 14, 2013, http://barentsobserver.com/en/arctic/2013/03/china-starts-commercial-usenorthern-sea-route-14-03.

29"China Issues Guidances on Arctic Navigation in the Northwest Route," China Maritime Safety Administration (MSA), April 19, 2016, http://en.msa.gov.cn/index.php? $\mathrm{m}=$ content\&c $=$ index\&a $=$ show\&catid $=343 \& \mathrm{id}=184$.

${ }^{30}$ Ryan Kilpatrick, “China's Plan for the Arctic - and a Shipping Centre to Rival Singapore," SCMP, November 15, 2016.

${ }^{31}$ The Arctic Council, "Arctic Council, Arctic Marine Shipping Assessment 2009 Report," April 2009, p. 5, https://oaarchive.arctic-council.org/handle/11374/54. 
Table 1. Northern Sea Route Transit Statistics for China (2011-2015) in Comparison with Suez Canal.

\begin{tabular}{lccc}
\hline Year & Total \# of Vessels: NSR & \# of China-Flagged Ships & Total \# of Vessels: Suez \\
\hline 2011 & 41 & 0 & 17,799 \\
2012 & 46 & 2 (1 Xuelong) & 17,224 \\
2013 & 71 & 1 (Hong Kong, China) & 16,596 \\
2014 & 52 & 0 & 17,148 \\
2015 & 18 & 2 & 17,483 \\
\hline
\end{tabular}

Source: Northern Sea Route Information Office \& Suez Canal Traffic Statistics. ${ }^{32}$

there would be cooperation among related actors when the now blocked corridors become more accessible.

Obviously, if the Arctic routes are available for round-the-year shipping, to facilitate trade with Europe, China would rely more on the NSR traversing along the north Siberian coast. This makes pragmatic cooperation with Russia all the more significant. Indeed, Russia appears to be better situated to provide required services for the safe Arctic passage. Compared to Canada, which controls the Northwestern Passage that runs through its archipelago, Russia has more extensive ice-

Emerging Arctic passages have displayed tremendous economic value for major trading nations like China. breakers and support fleets to assist trans-Arctic shipping. For comparison, Russia has six nuclear-powered icebreakers available in the region for NSR support as well as "several river and diesel icebreakers operating on a yearround basis," whereas "Canada operates five diesel-powered icebreakers only for seasonal (May-November) NWP operations." ${ }^{33}$ Besides technological and logistical calculations, China would be more interested in utilizing the NSR for Arctic shipping, especially considering that the China-led "Belt and Road" is a Eurasia-focused project and the NSR could assume a

${ }^{32}$ Northern Sea Route Information Office, http://www.arctic-lio.com/nsr_transits; Suez Canal Traffic Statistics, http://www.suezcanal.gov.eg/TRstatHistory.aspx?reportId=4.

${ }^{33}$ Carl Magnus Eger, "Comparison of Operational Conditions along the Arctic Routes," Arctics Knowledge Hub, 2010, http://www.arctis-search.com/Comparison+of+Operational+ Conditions + along + the + Arctic + Routes $\&$ structure $=$ Arctic + Sea + Routes. 
significant role in it by complementing the maritime leg of the project across the High North.

Apart from economic and scientific considerations, what brings the Arctic onto China's policy radar is its strategic importance. As another policy objective, which complements and supports those mentioned above, China intends to acquire all the necessary economic, scientific and technological capabilities to project power in the Arctic, and prepare for challenges and threats (such as Arctic militarization) to its national security.

In this respect, a potential large-scale militarization of the area would bring risks for China. Even though the melting of the Arctic sea ice due to milder climate makes it necessary to ensure security against "illegal border crossings, illegal emigration, organized crime and terrorists," the trend might eventually pave the way for an Arctic arms race among the primary stakeholders, thereby endangering the security and interests of the nonArctic states that utilize the Arctic routes and participate in resource development activities. ${ }^{34}$ As the Arctic becomes more strategically and economically valuable with growing accessibility, incongruences in national interest priorities may encourage related state actors to seek strategic advantage by increasing military capabilities in the region, causing security dilemmas among major powers.

Given such concerns, countries are considering Arctic affairs in a security context. The Arctic countries such as the United States, Russia and Canada have expressed intent to ensure national security by increasing military capabilities in the region. Currently, every major Arctic country has been training and equipping national armed forces for potential Arctic missions. For instance, "over the past few years the United States has maneuvered to increase the presence of the U.S. military above the Arctic circle," which comes in direct opposition to the political rhetoric that emphasizes not militarizing Arctic affairs. ${ }^{35}$ Similarly, in 2013, the Russian Navy sailed a fleet of 10 ships, which included a nuclear cruiser and several icebreakers, to the New Siberian Islands, one of the remotest points in the

${ }^{34}$ Ray Weaver, “Co-operation Doesn't Mean Militarisation, Says Russian Ambassador," The Arctic Journal, February 3, 2014, http://arcticjournal.com/politics/389/co-operationdoesnt-mean-militarisation-says-russian-ambassador.

${ }^{35}$ Ian Birdwell, “Future Roles for the Arctic Council," CIMSEC, October 25, 2016, http:// cimsec.org/future-roles-arctic-council/28860. 
Arctic Ocean. The move followed the announcement by the Russian Defense Ministry regarding a plan to establish an air base to increase its presence in the region and provide assistance to the shipping activities on the Northern Sea Route. ${ }^{36}$

Russia is also developing a heavy drone specifically for long-range Arctic surveillance missions, which is expected to be put into serial production in $2020 .^{37}$ Canada has announced its intention to reinforce its Arctic surveillance capacity via satellites. Toward this end, the Canadian government released plans to launch three satellites by 2018. Militarization of the Arctic is a possibility especially in the event that an actor's maneuver causes a series of countermoves by the corresponding parties that feel threatened. The U.S. strategists, for instance, are concerned about Russia's Arctic policy in terms of military development, such as the reopening of the Soviet-era military facilities and the establishment of a new Arctic command in December 2014. If this concern provides the required incentive for NATO to increase its presence in the region, an ensuing Arctic military build-up and arms race could trigger a chain of reactions by related parties, such as Russia - especially if NATO expands by adding Sweden and Finland as members (four of the five Arctic littoral states are already NATO members), which has been discussed among NATO members for a while now. Being a collective security organization tasked with defending the territorial integrity of its member states, NATO's enlargement would require an expansion of its security conceptualization to include the Arctic.

Thus, although NATO argued in 2013 that it did not have any "intention of raising its presence and activities in the High North" and the Strategic Concept and NATO Summit Declarations in 2010 (Lisbon), 2012 (Chicago), 2014 (Wales), 2016 (Warsaw) did not even refer to the Arctic, Russia, the only non-NATO littoral state, finds the assurance unconvincing. As a matter of fact, "the militaries of most Arctic states are taking on new and expanded roles in the region that go beyond their traditional responsibilities," a phenomenon that is observed in the development of nuclear

${ }^{36}$ Ray Weaver, "The New Cold War," The Arctic Journal, October 30, 2013, http://arcticjournal.com/politics/218/new-cold-war.

37 "Russia is Developing a Heavy Drone for the Arctic Region," Russian Aviation, June 9, 2016, http://www.ruaviation.com/news/2016/6/9/5634/?h. 
offense and defense capabilities led by Russia and the United States in the Arctic. ${ }^{38}$ While Russia wants to reinforce its submarine-based missile arsenal concentrated on its Northern Fleet, the United States has been beefing up its anti-ballistic missile defense systems in Alaska.

Indeed, the melting of the sea ice and growing prospects of access to resources and shipping routes give incentives to defense and security establishments in circumpolar nations to expand military activities and develop new security doctrines with an eye to the Arctic. The three Arctic passages, in this regard, provide certain military advantages whereas the question of accessibility remains. Studies show that both the NSR and the NWR can be utilized for submarine deployment. Thus, even if developments in missile technology enable intercontinental nuclear strike from warmer waters without having to deploy submarines into the Arctic, the strategic location of the region overlooking three continents cannot be ignored by major countries (as was the case during the Cold War). The region might eventually become a strategic theater for offensive and defensive missile and submarine deployments. ${ }^{39}$

China may face grave security challenges in time to come, given the rising geopolitical competition in the Arctic.

In this respect, China cannot rule out the possibility of Arctic militarization, especially when it is involved more heavily in the development of Arctic resources. In fact, at the strategic level, any offensive (long-range missiles capable of carrying nuclear warheads) and defensive (anti-missile systems designed to detect, track and destroy incoming missiles) deployment on the Arctic territories would endanger China's security, making it more vulnerable to attacks from a shorter distance by undermining its response and second-strike capability. Therefore, peaceful utilization and non-militarization of the Arctic would be of paramount significance for China. If the Arctic sees growing military activities

${ }^{38}$ Rob Huebert, “Rob Huebert: It's Time to Talk About Arctic Militarization,” National Post, May 6, 2013, http://news.nationalpost.com/full-comment/arctic-piece-1-for-monday.

${ }^{39}$ Willy Østreng, "Military and Civil Activities along the Arctic Routes," Arctics Knowledge Hub, 2010, http://www.arctis-search.com/Military+and+Civil+Activites+along+ the + Arctic + Routes. 
(especially nuclear submarine presence and missile systems in and around the more accessible Central Arctic Sea), China would be forced to develop technologies and policies to avert potential threats. In addition to all the above considerations, China also continues its endeavors to improve and expand scientific programs to study the Arctic and combat climate change, given that China has been a member of the International Arctic Science Committee since 1996.

\section{Opportunities and Challenges for China's Arctic Strategy}

Since China has various policy considerations on the Arctic issue, it is anticipated that China will be further engaged in Arctic affairs, with the aim of building a conceptually and materially sound Arctic strategy. The Arctic Ocean is surrounded by five coastal states and regions (Russia, Alaska, Greenland, Canada and Norway) and, beyond the 200-nautical mile (NM) exclusive economic zone (EEZ) under the legal coverage of the United Nations Convention on the Law of the Sea (UNCLOS), 2.8 million square kilometers of the ocean are international waters covered with permanent frost. The opening-up of the areas within the maritime boundaries of coastal states such as Russia, Canada and the United States due to melting of the sea ice brings up two questions: cooperation in sovereign waters and unilateral and multilateral actions in international waters - as they become accessible for exploration and exploitation. In this scheme of things, China, as a rising global power, cannot be ignored or sidelined in the Arcticrelated developments, given the fact that in terms of economic, technological and industrial capacity, China enjoys an ever-growing status and thus is capable of drafting and executing unilateral strategies in the absence of bilateral and multilateral frameworks.

Thus, China will be likely to invest more national resources into Arcticrelated research and development, accelerate efforts to draft a detailed Arctic policy blueprint to make sure that the country is prepared to be fully engaged in the increasingly significant region, and adopt a proactive Arctic strategy where it maintains cooperative and collaborative presence in the Arctic-related frameworks. If China does not develop viable policies and strategies but contends to be a reactive spectator, the developments in the Arctic might have undesirable impact on its security and economic prospects. The fact that the Arctic is governed by regional and international 
laws as well as by the domestic rules and regulations of each Arctic state provides the necessary leeway for China to position itself as both a powerful international actor and an initiator of original ideas and frameworks.

Unilateralism is emphasized here because multilateral arrangements might not always be in China's favor, also because overlapping territorial and jurisdiction claims and disagreements, as well as competition over natural resources might further complicate the Arctic management. China's participation in the Arctic Council, in this respect, may prove to be consequential, since China's national capabilities are disproportionately larger than the rest of non-Arctic participants. This reality may lead major Arctic stakeholders to develop unhealthy suspicion towards China's political and security-related activities. Countries may band up together and try to stem China's rising influence in the Arctic development.

There are historical precedents that justify such a concern. For example, Iceland rejected (twice) the bids by a Chinese investor to buy a 300square-kilometer land in the country's northern coast, as it viewed the offer as a clandestine effort to build an Arctic port. ${ }^{40}$ In 2014, concerned by a slew of developments such as China's mineral exploration activities in Greenland, Xue Long's first trip in 2012 along the NSR, the launch of the Arctic Research Center, and Beijing's attempt to gain oil exploration rights in Iceland following the signing a free trade deal with the country in April 2013, Moscow gave its full support to Japan's entry into the Arctic Council, seeking a closer partnership with Tokyo in an apparent effort to balance China's growing influence. Although Russia's move was by no means an act of strategic hostility (considering that it already has numerous cooperation agreements with China to develop Arctic energy resources), the development nonetheless suggests an attempt by an Arctic state to diversify its strategic options by setting up cooperation schemes with Northeast Asian neighbors such as Japan and South Korea. Similarly, in 2012, the EU industry commissioner Antonio Tajani urged the Greenland government not to give Chinese companies rights to explore rare earth materials in the country and promised development aid from the EU in return for Greenland's compliance. Although the EU commissioner's efforts turned out to be unfruitful as the Greenland government declined the offer and stated that

40 "Iceland Rejects Chinese Investor's Land Bid," Financial Times, November 26, 2011, https://www.ft.com/content/26b0f8e2-178a-11e1-b157-00144feabdc0. 
there was no reason as to why it would favor the EU over China, the development still made obvious the potential political risks and challenges that China could face in the Arctic as it sought greater involvement. ${ }^{41}$

The economic and political significance of the Arctic for China's national interests cannot be underestimated. Scientific developments, in this respect, support both economic and security dimensions of China's Arctic policy. ${ }^{42}$ The economic aspect brings about broad potential security implications. Economically, the opening-up of the Arctic due to decreasing sea ice levels extends the opportunity to explore the formerly inaccessible energy and mineral deposits. For the areas that fall under the ju-

China's growing capabilities and stronger posture in Arctic affairs have triggered concerns from Arctic countries. risdiction of the states encircling the Arctic, investment and exploration partnerships with Scandinavian countries and Russia appear to be more feasible and, so far, the most successful. Toward this end, China has already embarked on various partnerships with Russia, Greenland and other Nordic stakeholders. The potential opening-up of the Central Arctic Sea, however, requires an international Arctic resources governance regime since those areas are international waters. In the absence of a governance framework, national capability of exploring and developing resources independently would become as important as participating actively in the international Arctic regime.

The potential of the Arctic as a sea route between East Asia and Europe is likely to have more security implications than resource development, because it brings about the question of security of the sea-lanes of communication. As mentioned above, provided that a full-scale utilization

41 “Greenland Rare Earths: No Special Favors for the EU,” BBC, 15 Jan 2013, http:// www.bbc.co.uk/news/world-europe-21025658.

${ }^{42}$ Scientifically, China's involvement in Arctic research, other than acquiring substantial marine and geographic knowledge, enables the country to study the area for the use of waterways for commercial and governmental purposes, and support and develop shipping industries for advanced marine vehicles. Currently China has only one heavy ice breaker with the second one anticipated to be completed by 2018. "Bidding to Start on China's New Ice Breaker," Maritime Executive, March 13, 2016, http://www.maritime-executive.com/article/bidding-to-start-on-chinas-new-ice-breaker. 
becomes possible, the Arctic passages will offer a more economical way of delivering goods and commodities to European markets. For China, the Arctic represents yet another sea-lane to avoid the lengthy and potentially more volatile southwestern route via the South China Sea and the Indian Ocean. Although the ongoing China-Pakistan Economic Corridor (CPEC), which involves extensive transportation and energy infrastructure networks, can be viewed as a practical response to the Malacca Dilemma, still, the Arctic Route offers additional advantages such as a direct shipping link to major European ports and shorter delivery time.

Yet, just as the southwestern route via the South China Sea raises the question of sea-lane security in the Western Pacific and Indian Oceans due to territorial disputes and the presence of the U.S. Navy, as well as other non-state threats such as piracy and terrorism, the utilization of the northern route across the Arctic would bring about similar concerns, albeit on a relatively smaller scale. If the Arctic route were more intensively utilized, the issue of East China Sea security would emerge - especially considering the heavy presence of the U.S. military both in Japan and South Korea and the ongoing territorial dispute between China and Japan over the Diaoyu Islands. In both cases, the question of security along the First Island Chain remains. As China develops new policies for new maritime trade routes and dedicates significant amount of national resources, the reality of maritime encirclement cannot be neglected, which also brings up the issue of Taiwan's reunification with the Mainland as the most practical way of breaking through the First Island Chain. Accordingly, the openingup of new trade routes across the Arctic would necessitate a greater Chinese naval presence and an enhanced power projection capacity because of a larger number of strategic theaters.

Cooperation with Russia is of economic and strategic importance, considering that the Northern Sea Route, which provides a potential trade route between the Asia-Pacific and Western Europe, enables a significant reduction in shipping cost and duration, even though the route's accessibility still depends on the seasonally variable ice conditions and requires icebreaker and navigation assistance. ${ }^{43}$ For example, when compared to the

${ }^{43}$ According to the Northern Sea Route Information Office of Russia, "Navigation season for transit passages starts approximately at the beginning of July and lasts through to the second half of November," http://www.arctic-lio.com/nsr_generalareadescription. 
Suez Canal, the distance between Shanghai-Hamburg (despite the exact distance depending on the route taken through the NSR) would be about 8,034 NM, which is 26 percent shorter than that between Shanghai to Hamburg via the Suez Canal (11,400 NM). Likewise, the total journey duration via the NSR (23 days) would be much less than that via the Suez Canal (34 days), assuming that the service speed along the two routes is identical. ${ }^{44}$ Thus, even when higher costs of insurance and icebreaker service are considered, the NSR route makes more sense economically. Although not possible currently, in the event that the route becomes navigable without icebreaker support, the distance-cost ratio would change further in favor of the Arctic route.

The Arctic is also a significant front in the expanding China-Russia energy relationship. Given that geopolitics carries great weight in Arctic-related energy policy making, the existing rift between Russia and the U.S./EU offers a certain advantage for Chinese energy corporations to seek new ties with Russia in the Arctic. As the U.S.-led sanctions made it impossible for Russian oil companies to continue exploration activities

To promote its economic and security interests in the Arctic, China needs to foster a closer partnership with Russia. in the Arctic, the Rosneft had to reduce drilling at Universitetiskya-1 oil field in the Kara Sea after Exxon-Mobil left. It is very likely that the space emptied by the Western investment will be filled by others. Thus, Russian, Indian and Chinese foreign ministers discussed the prospects for cooperation in oil and natural gas exploration in the Arctic during their meeting in $2015 .{ }^{45}$ Over the years, numerous reports have been released regarding China's participation in shelf energy and extraction projects in the Russian Arctic. For example, in March 2013, China's CNPC signed a joint development agreement with Rosneft for the exploration of three fields in the Barents and Pechora Seas. In September 2015, China

${ }^{44}$ Tor Wergeland, "Arctic Shipping Routes - Cost Comparisons with Suez," 2010, CHNL. http://www.arctis-search.com/Arctic+Shipping+Routes+-+Cost+Comparisons+with+Suez.

${ }^{45}$ Kabir Taneja, “China and India go Arctic," Politico, August 14, 2014, http://www. politico.eu/article/china-and-india-go-arctic-sanctions-gas-oil-exploration-lng/. 
Oilfield Services Limited (COSL) signed multiple deals with Russian Rosneft and Norwegian Statoil to drill two exploration fields in the Sea of Okhotsk.

China-Russia cooperation can be extended to the military use of the Arctic, especially when the two countries face similar high seas security challenges. Russia, for that matter, unlike the United States or Britain which can use home bases to have access to high seas, has to use the Arctic Ocean for strategic operations, as it is cut off from high waters on the south, even though Russian submarine forces are quite developed and able to maintain sustained presence in all waters across the world. To add another strategic dimension to the existing comprehensive partnership, the two sides may seek common ground in their Arctic strategies and address the prevailing distrust and misunderstandings. In this regard, the Russian side needs to be assured of China's respect for Moscow's territorial sensitivities, which are often expressed by Russian military personalities such as Admiral Vladimir Vysotsky who argued that China joined the countries which wanted "a piece of the Arctic Pie" by "advancing their interests very intensively, in every possible way." 46

\section{Conclusion}

This article reveals that China's evolving Arctic policy draws on some fundamental understandings. Even though China does not have Arctic coastlines, its economic and security interests are becoming increasingly linked to Arctic development. Thus, the "near Arctic state" formulation ensures that China's interests are pursued and protected. The "Arctic as an international sphere" formulation suggests that even if China recognizes the rights and responsibilities of the countries with geographical presence in the Arctic, the non-Arctic states, too, have "certain rights in maritime areas, including the deep seabed, the high seas, and within coastal states' exclusive economic zones." ${ }^{\prime 4}$ As a near Arctic state with immense trade

${ }^{46}$ The Atlantic Council, “Commander of the Russian Navy Warns of China's Race for Arctic," October 4, 2010, http://www.atlanticcouncil.org/blogs/natosource/commander-ofthe-russian-navy-warns-of-chinas-race-for-arctic.

${ }^{47}$ Timo Koivurova, "Demystifying the EU in the Arctic," News Deeply, February 29, 2016, https:/www.newsdeeply.com/arctic/community/2016/02/29/the-eu-in-the-arcticcorrecting-misconceptions. 
penetration across the globe, rising scientific capabilities, and growing natural resources utilization, China definitely has greater stakes in the Arctic than any other non-Arctic country.

Considering this reality, China's Arctic strategy is set to grow into a comprehensive road map centered on specific economic, political and scientific considerations. Economically, the opening-up of Arctic trade routes is of great significance especially with respect to China's efforts to diversify its global trade linkages and develop hydrocarbon and mineral resources. Politically, the likelihood of Arctic militarization makes China a direct stakeholder, because of its prominent status as a permanent member at the United Nations Security Council (UNSC) with legitimate nuclear capability and as the world's largest trading nation with major economic interest in ensuring the security of global trade routes, including the now more accessible Arctic sea corridors. Also, Arctic-related scientific research and technological development are important for studying the causes and effects of global warming and preventing environmental degradation in the Arctic.

It is reported that "while China does not have Arctic territory, it is investing millions of dollars in Arctic research, infrastructure, and natural resource development." ${ }^{\prime 8}$ Apparently, although China started relatively belatedly to develop its Arctic policy, significant progress has been made. Institutionally, specific government agencies have been assigned to formulate a national strategy. China has also achieved a certain level of capability to develop Arctic-related energy and transportation technologies and invested significantly in Arctic research. Similarly, at the diplomatic level, as a permanent observer in the Arctic Council, China has participated in numerous bilateral and multilateral cooperation and partnership frameworks in the fields of energy, maritime transportation and environmental research. These conditions, therefore, are more amenable for the development of a national Arctic strategy in which all aspects of Arctic development (economic, strategic and scientific) can be considered and addressed in a comprehensive way.

${ }^{48}$ U.S. National Petroleum Council, "Arctic Potential: Realizing the Promise of U.S. Arctic Oil and Gas Resources," 2015, http://www.npcarcticpotentialreport.org/pdf/ AR_Exec_Summary.pdf. 